\title{
Production of Actinomycin D in Complex Media
}

\author{
Part I. The Influence of Metal Ions
}

\author{
R. I. Mateles and A. Ben-Bassat \\ Laboratory of Applied Microbiology, Hebrew University-Hadassah Medical School, \\ P. O. Box 1172, Jerusalem, Israel
}

Received March 12, 1973

\begin{abstract}
The production of actinomycin D was examined using Streptomyces antibioticus growing on a complex medium based on glucose and casein hydrolyzate. Purification of the medium to remove calcium increased actinomycin production by about one-third and prevented production of a characteristic brown pigment. The sensitivity to magnesium concentrations was less than was reported by Katz et al., ${ }^{11}$ while similar requirements were found for zinc and iron.
\end{abstract}

Although actinomycin has been known for thirty years ${ }^{1,2}$ and has been the subject of a number of reports dealing with the biosynthesis of the actinomycin complex in defined media, relatively few have dealt with its production in commercial-type media involving complex organic nitrogen sources, and those that have appeared emphasized primarily the effect of amino acids on the types of actinomycin produced. $^{3,6)}$

Production of actinomycin D, important mainly in biological research, but also in treatment of certain tumors, is readily carried out in inexpensive glucose-based complex media. ${ }^{7}$ This paper reports the results of an investigation of the effect of varying concentrations of some metal ions on actinomycin production in such media.

\section{MATERIALS AND METHODS}

Microorganism. Streptomyces antibioticus was obtained from Dr. E. Katz. Spores were produced on sporulation agar (yeast extract, Difco, 1.0; beef extract, Difco, 1.0; tryptose 2.0; glucose, 10.0; agar, $30.0 \mathrm{~g} /$ liter; $\mathrm{pH} 7.0$; tap water) by incubation in Roux bottles, $7 \sim 8$ days at $28^{\circ} \mathrm{C}$. Spores were harvested in $0.1 \%$ sodium lauryl sulfate solution and used at a concentration of $1 \sim 5 \times 10^{9}$ spores per $\mathrm{ml}$.

Inocula and production media. The vegetative inoculum was grown in a medium comprising $10 \mathrm{~g}$ of beef extract, and $25 \mathrm{~g}$ of $\mathrm{N}-\mathrm{Z}$ Amine $\mathrm{B}$ (Sheffield), per liter of tap water. The purified production medium contained $20 \mathrm{~g}$ of $\mathrm{N}-\mathrm{Z}$ Amine $\mathrm{B}$ (purified as described below), $10 \mathrm{~g}$ of glucose, $0.6 \mathrm{~g}$ of $\mathrm{KH}_{2} \mathrm{HPO}_{4}, 1.4 \mathrm{~g}$ of $\mathrm{K}_{2} \mathrm{HPO}_{4}, 25 \mathrm{mg}$ of $\mathrm{ZnSO}_{4} \cdot 7 \mathrm{H}_{2} \mathrm{O}, 25 \mathrm{mg}$ of $\mathrm{MgSO}_{4}$. $7 \mathrm{H}_{2} \mathrm{O}$, and $25 \mathrm{mg}$ of $\mathrm{FeSO}_{4} \cdot 7 \mathrm{H}_{2} \mathrm{O}$, per liter of double distilled water.

Purification of the $\mathrm{N}-\mathrm{Z}$ Amine B was carried out by bringing the $\mathrm{pH}$ of 5 liters of $2.4 \%$ solution to 12 with $\mathrm{NaOH}$ and storing at $4^{\circ} \mathrm{C}$ ior $4 \sim 5 \mathrm{hr}$. A precipitate was removed by filtration and the solution was passed first through a column of $50 \mathrm{~g}$ of $50 \sim 100$ mesh Dowex 50 (Fluka) and then through a column of $30 \mathrm{~g}$ of $50 \sim$ 100 mesh Chelex 100 (Bio-Rad), both of which had been exchanged into the $\mathrm{Na}^{+}$form and then thoroughly washed with $0.01 \mathrm{~N} \mathrm{NaOH}$. The $\mathrm{N}-\mathrm{Z}$ Amine was washed through with $0.01 \mathrm{~N} \mathrm{NaOH}$, the solution was adjusted to $\mathrm{pH} 7.0$ with $\mathrm{HCl}$, and brought to a final volume of 6.0 liter with distilled water, giving a solution containing $20 \mathrm{~g}$ per liter based on the original amount of N-Z Amine B. The other nutrients were then added to this solution, and the complete medium was sterilized $20 \mathrm{~min}$ at $121^{\circ} \mathrm{C}$ in shake flasks. For the fermentor runs, sterilization was $30 \mathrm{~min}$ at $121^{\circ} \mathrm{C}$, and the glucose was sterilized separatively and added aseptically.

Culture techniques. Four $\mathrm{ml}$ of the spore suspension was inoculated into $200 \mathrm{ml}$ of inoculation medium contained in a 1 liter Erlenmeyer flask. After incubation at $28^{\circ} \mathrm{C}$ on a gyrotory shaker $(250 \mathrm{rpm})$ for 2 days, the cells were centrifuged $(15000 \times g, 10 \mathrm{~min})$, washed twice with sterile distilled water, and resuspended in $200 \mathrm{ml}$ of sterile distilled water.

One $\mathrm{ml}$ of this suspension was used as inoculum for each $250 \mathrm{ml}$ Erlenmeyer flask containing $100 \mathrm{ml}$ of the appropriate production medium.

Production flasks were incubated as above for $7 \sim 8$ 
days.

Assays. The concentration of actinomycin was determined by extracting an aliquot of broth with ethyl acetate, and reading the optical density of the extract at $443 \mathrm{~nm}$. The extinction coefficient used was $24,800 .^{81}$ The concentration of components of the actinomycin complex was determined by elution of the bands following circular chromatographys) and recoveries were in the range of $98 \sim 103 \%$.

The concentration of iron, zinc, calcium, potassium magnesium, and sodium were determined by atomic absorption spectrometry, ${ }^{9}$ using a Perkin-Elmer Model 403 atomic absorption spectrophotometer.

Inorganic and organic phosphate was determined according to Ames. ${ }^{10}$

\section{RESULTS AND DISCUSSION}

Ion exchange purification of $N-Z$ Amine solution

Table I shows the concentration of the metals found in the $\mathrm{N}-\mathrm{Z}$ Amine solution before and after ion exchange purification. The increase in the sodium concentration was caused principally by the sodium hydroxide used to adjust the $\mathrm{pH}$ and to rinse the columns. The removal of divalent cations was adequate, while the concentration of potassium was unchanged.

Table I. Concentration of Metals in $\mathrm{N}-\mathrm{Z}$ AMINE B SOLUTION $(20 \mathrm{~g} /$ liter) BEFORE AND after Ion Exchange Purification

\begin{tabular}{lcc}
\hline Metal & $\begin{array}{c}\text { Concentration }(\mu \mathrm{g} / \mathrm{ml}) \\
\text { Before ion } \\
\text { exchange }\end{array}$ & $\begin{array}{c}\text { After ion } \\
\text { exchange }\end{array}$ \\
\hline $\mathrm{Na}$ & 330.00 & 1200.0 \\
$\mathrm{~K}$ & 0.90 & 0.90 \\
$\mathrm{Ca}$ & 8.50 & 0.20 \\
$\mathrm{Mg}$ & 0.90 & 0.003 \\
$\mathrm{Zn}$ & 0.39 & 0.06 \\
$\mathrm{Fe}$ & 0.95 & 0.14 \\
\hline
\end{tabular}

\section{Actinomycin production}

With the strain of microorganism, and the culture used, it was found that at the time of peak production of the actinomycin complex, on the sixth day, actinomycin D amounted to $70 \sim 80 \%$ of the total actinomycins.

Table II shows the results obtained in a series of experiments to determine the effect

\section{Table II. The Effect of Metal Ion Concent-} RATION ON ACTINOMYCIN YIELD

The purified production medium was used, except that the concentration of the appropriatesalt was changed to obtain the metal ion concentrations reported, all the others being held at the values described in "MATERIALS AND METHODS." Each concentration was run in triplicate, and the yields reported are the means.

\begin{tabular}{|c|c|c|}
\hline Metal & $\begin{array}{l}\text { Concentration } \\
\text { (microgm } / \mathrm{ml} \text { ) }\end{array}$ & $\begin{array}{r}\text { Actinomycin } \\
(\mathrm{microgm} / \mathrm{ml})\end{array}$ \\
\hline \multirow[t]{5}{*}{ K } & $0.9^{a 1}$ & 47 \\
\hline & 14 & 103 \\
\hline & 53 & 97 \\
\hline & 263 & 88 \\
\hline & 1049 & 95 \\
\hline \multirow[t]{4}{*}{$\mathrm{Ca}$} & $0.2^{a)}$ & 133 \\
\hline & 1.0 & 98 \\
\hline & 4.0 & 93 \\
\hline & 171 & 84 \\
\hline \multirow[t]{5}{*}{$\mathrm{Mg}$} & $0.003^{a)}$ & $-b$ \\
\hline & 0.25 & 95 \\
\hline & 1.2 & 100 \\
\hline & 12 & 88 \\
\hline & 62 & 90 \\
\hline \multirow[t]{4}{*}{$\mathrm{Zn}$} & $0.06^{a}$ & $-^{(b)}$ \\
\hline & 1.0 & 105 \\
\hline & 6.0 & 117 \\
\hline & 28 & 104 \\
\hline \multirow[t]{4}{*}{$\mathrm{Fe}$} & $0.14^{a}$ & -61 \\
\hline & 1.0 & 102 \\
\hline & 5.0 & 105 \\
\hline & 25 & 84 \\
\hline
\end{tabular}

a) This represents the residual concentration after ion exchange purification.

b) No growth was obtained, and no actinomycin production was observed.

of varying metal ion concentrations. The flasks were sampled at daily intervals, and the peak concentration was usually obtained on the sixth day.

In the case of potassium, potassium phosphate was omitted from the basal purified medium, and potassium was added as the chloride. The $\mathrm{N}-\mathrm{Z}$ Amine itself was found to contain sufficient phosphate to yield a total phosphate concentration of $0.45 \mathrm{~g}$ per liter, of which $0.12 \mathrm{~g}$ per liter was inorganic phosphate. With no added potassium the yield was reduced by about $50 \%$, and the peak yield was obtained about one day later than normal. 
When calcium was omitted from the purified medium, the yield of actinomycin was increased by about a third. Under these conditions, there was also no production of a characteristic brown pigment, which normally accompanied actinomycin production with this strain. This beneficial effect of lowering the calcium concentration is somewhat in contradiction to the results reported by Katz et al., ${ }^{11}$ who used a defined synthetic media and found that $5 \mathrm{mg} /$ liter of $\mathrm{Ca}^{2+}$ gave a maximum yield of actinomycin.

Similarly, a significant difference in sensitivity to magnesium concentration is noted. In the earlier work ${ }^{11)}$ the optimum was found to be $2.4 \mathrm{mg} / \mathrm{liter}$, but changing the concentration by a factor of 2 reduced it by $50 \%$ while raising it to about $10 \mathrm{mg} /$ liter reduced the actinomycin production to zero. In this investigation, as may be seen from Table II, the optimum is about $1.2 \mathrm{mg} /$ liter, with little effect of $\mathrm{Mg}^{2+}$ concentration on actinomycin production in the range between $0.25 \sim 62 \mathrm{mg} /$ liter.
The requirements for zinc and iron reported here are consistent with those reported by Katz et al. ${ }^{11}$ ?

\section{REFERENCES}

1) S. A. Waksman and H. B. Woodruff, Proc. Soc. Exp. Biol. Med., 45, 609 (1940).

2) S. A. Waksman and H. B. Woodruff, U.S. Patent 2,378,876, (1945).

3) W. A. Goss and E. Katz, Appl. Microbiol, 5, 95 (1957).

4) E. Katz, "Actinomycin," ed. by S. A. Waksman, John Wiley and Sons, Inc., New York, 1968, pp. $45 \sim 68$.

5) G. Schmidt-Kastner, Naturwissenschaften, 43, 131 (1956).

6) E. Katz and W. A. Goss, Biochem. J., 1959, 458.

7) H. B. Woodruff and S. A. Waksman, "Actinomycin," ed. by S. A. Waksman, John Wiley and Sons, Inc., New York, 1968, pp. 15 31.

8) E. Katz, A. B. Mauger and H. Weissbach, Molec. Pharmacol, 1, 107 (1965).

9) W. Slavin, "Atomic Absorption Spectroscopy," John Wiley and Sons, Inc., New York, 1968.

10) B. N. Ames, Methods in Enzymology, 8, 115 (1966).

11) E. Katz, P. Pienta and A. Sivak, Appl. Microbiol., 6. 236 (1958). 